(C) Petrushanko T.O., Krutikova A.D., Krutikova E.I.

UDC: 616.31-002-06:618.15-022.7]-08:616-07

DOI https://doi.org/10.31718/mep.2019.23.3-4.05

\title{
DIAGNOSTIC VALUE OF LABORATORY TESTS OF WOMEN IN THE DYNAMICS OF TREATMENT OF PERIODONTAL DISEASES CONCOMITANT WITH BACTERIAL VAGINOSIS
}

\author{
Petrushanko T.O., Krutikova A.D., Krutikova E.I. \\ Ukrainian Medical Stomatological Academy, Poltava
}

Відсутність тактики стоматологічного обстеження жінок, що страждають на бактеріальний вагіноз (БВ), призводить до неадекватного планування лікування, оскільки не звертається увага на нетипові провокуючі фактори, не дивлячись на доведенність факту наявності у пацієнток із БВ хронічних генералізованих запальних та запальнодистрофічних захворювання пародонта. Важливим моментом неінвазивної діагностики $\epsilon$ аналіз стану ротової рідини, $\epsilon$ кінетична активність альфа-амілази та sIgA. Метою роботи стала перевірка діагностичної цінності оцінки результатів найближчого лікування запальних та запально-дистрофічних захворювань пародонта у жінок репродуктивного віку із бактеріальним вагінозом шляхом визначення зміни показників кінетичної активності альфаамілази та концентрації sIgA. Матеріали та методи. Обстежено 50 жінок репродуктивного віку. Поділ по групам проведено згідно гінекологічного статусу пацієнток: група контролю (I) - 10 жінок з I та II ступенями чистоти піхви, II група - 10 пацієнток, що є носіями Gardnerella vaginalis, але діагноз БВ не встановлено, III-A група - 15 жінок, що з БВ та були проліковані за загальноприйнятою методикою, III-Б група - 15 осіб із БВ, які застосовували запатентовану нами схему лікування. У порожнині рота аналізували результати проведення аміно-тесту ротової рідини, визначали кінетичну активність альфа-амілази та концентрацію sIgA. Методом полімеразноланцюгової реакції (ПЛР) визначали наявність Gardnerella vaginalis та Atopobium vaginae у порожнині рота. Результати Рівень SIgA жінок із БВ знижений на 30-45\%, порівняно з показником пацієнток, без БВ. Концентрація sIgA ротової рідини у жінок обох груп відновилася після лікування, але показники III-A та III-Б групи після лікування достовірно різнилися (результат SIgA у осіб III-Б групи вищий за показник III-A групи у 1,33 рази), що говорить про вищу ефективність запропонованої схеми лікування Результати аміно-тесту ротової рідини був позитивним у пацієнток III-А групи до лікування у 73,3\%, після лікування -лише у 53,3\%, в той час як у обстежених III-Б груп початковий результат склав 80\%, після лікування зареєстровано зниження до 20\%. Висновки. Діагностична цінність використаних лабораторних методів обстеження жінок їх місцевої резистентності $\epsilon$ достатньою для масового використання в якості контролю результатів пародонтологічного лікування пацієнтів із запальними та запально-дистрофічними хворобами пародонта, асоційованими бактеріальним вагінозом.

Ключові слова: лікування пародонтиту та гінгівіту, бактеріальний вагіноз, амінотест, концентрація slgA, кінетична активність альфа-амілази

The lack of clear dental screening strategy for women with bacterial vaginosis (BV) leads to inadequate treatment planning, since atypical triggering factors are not considered, despite the given evidence for the presence of chronic generalized inflammatory and inflammatory-dystrophic periodontal diseases in patients with BV. The analysis of the oral fluid, especially its protective properties, is crucial in the noninvasive diagnostics. In this regard, alpha-amylase and secretory $\operatorname{IgA}(\mathrm{sIgA})$ are noteworthy. The aim of the research. The paper was aimed at verification of the diagnostic value of the assessment of the outcomes of the recent treatment of inflammatory and inflammatory-dystrophic periodontal diseases in women of reproductive age with bacterial vaginosis by determining the changes in the kinetic activity of alpha- amylase and sIgA concentration. Material and Methods. 50 women of reproductive age have been examined. The subjects were assigned into groups according to their gynecological status: Group I (control) $(n=10)$ included women with the I and II degree of purity of the vagina Group II $(n=10)$ included carriers of Gardnerella vaginalis without diagnosed bacterial vaginosis ; Group III-A ( $n=15)$ included women with verified diagnosis of BV who received conventional treatment; Group III-B $(n=15)$ included women with $B V$, who received treatment using our patented treatment regimen that takes into account the presence of specific BV-microflora found in the oral cavity in this group of subjects. In the oral cavity the results of the amino-test of the oral fluid were analyzed and kinetic activity of alpha-amylase and sIgA concentration was determined. The presence of Gardnerella vaginalis and Atopobium vaginae in the oral cavity was determined by the polymerase chain reaction (PCR) method. Results. The sIgA level of women with BV was by 30-45\% lower as compared to the value of patients without BV. Concentration of oral SIgA in both groups of women was restored after treatment, but the results of the III-A and III-B groups after treatment significantly differed (the result of sIgA in subjects of Group III-B was by 1.33 times higher than the value of Group III-A), indicating the higher efficacy of the proposed treatment regimen, which takes into account the presence of etiological agents of $B V$ in the oral cavity. The results of the amino test of oral fluid were positive in patients of Group III-A before treatment in $73.3 \%$, after treatment only in

To cite this english version: Petrushanko T.O., Krutikova A.D., Krutikova E.I. Diagnostic value of laboratory tests of women in the dynamics of treatment of periodontal diseases concomitant with bacterial vaginosis. // The Medical and ecological problems. - 2019. - Vol 23, № 3-4. - P. $17-21$. 
Tom 23, N 3-4 2019 p.

$53.3 \%$, while in the subjects of Group III-B the initial result was $80 \%$; after treatment, a decrease to $20 \%$ was registered. Conclusions. The diagnostic value of the applied laboratory methods for examination of local resistance in women is sufficient for mass use as a control of the results in periodontal treatment of patients with inflammatory and inflammatory-dystrophic periodontal diseases concomitant with bacterial vaginosis.

Keywords: treatment of periodontitis and gingivitis, bacterial vaginosis, amino-test, slgA concentration, kinetic activity of alpha-amylase

\section{Introduction}

Inflammatory and dystrophic periodontal diseases constitute a problem that requires a comprehensive and interdisciplinary approach both in the diagnosis and treatment, since generalized periodontitis is one of the manifestations of numerous somatic diseases. The relation between pathologies of the cardiovascular, nervous, endocrine, digestive, respiratory and immune systems of the body and periodontal lesions has been validated $[9,3]$ and the algorithms for management of such patients have been developed. The lack of clear dental screening strategy for women with bacterial vaginosis (BV) leads to inadequate treatment planning, since atypical triggering factors are not considered, despite the given evidence of presence of chronic generalized inflammatory and inflammatory-dystrophic periodontal diseases in patients with BV $[2,3,13]$.

Currently, the incidence rate of BV in women aged $18-45$ years is accounted for $67 \%-89 \%[7,8]$. The WHO defines bacterial vaginosis as a polymicrobial dysbiotic noninflammatory disease, when the specific and qualitative vectors of the vaginal microflora are shifted to anaerobic microorganisms. The main etiological agents of BV are Gardnerella vaginalis, an optional anaerobe, found in $82 \%$ of women with the abovementioned diagnosis, and Atopobium vaginae, which causes frequent clinical relapses $[6,8,12]$. Considering the prevalence of the mentioned gynecological diagnosis and detection of inflammatory and inflammatory- dystrophic periodontal diseases in women of reproductive age [13], it is advisable to focus on a more detailed examination of women with bacterial vaginosis and clinical manifestations of the inflammatory-dystrophic process in periodontal tissues.

The analysis of the oral fluid, especially its protective properties, is crucial in the noninvasive diagnostics. In this regard, alpha-amylase and secretory $\lg \mathrm{A}(\operatorname{sg} \mathrm{A})$ are noteworthy. Alpha-amylase of saliva ensures hydrolysis of carbohydrates at the level of $\alpha-1,4$-glycosidic bonds, responsible for the destruction of cell walls of various microorganisms (for example, cleavage of alpha-glucans in the cell wall of fungi). The normal value of quantitative kinetic activity of this enzyme in the human oral fluid is 160-320 units. In the presence of inflammatory process in the oral cavity, the kinetic activity of the enzyme increases to 500-620 units [2].

slgA is the main type of immunoglobulins involved in local immunity of the oral cavity. This component of the oral fluid limits the adhesion of microorganisms to the surface of the epithelium and teeth, resulting in the neutralization of enzymes, toxins, and viruses, or acts synergistically with other antibacterial agents such as lysozyme, lactoferrin of saliva peroxidase. The normal concentration of slgA in saliva is 115.3-299.7. Reduction of slgA concentration in saliva is stated in chronic inflammatory diseases of the oral cavity, reinfections and allergic reactions $[8,12,13]$.

The aim of the research. The paper was aimed at verification of the diagnostic value of the assessment of the outcomes of the recent treatment of inflammatory and inflammatory-dystrophic periodontal diseases in women of reproductive age with bacterial vaginosis by determining the changes in the kinetic activity of alpha- amylase and sigA concentration.

\section{Materials and Methods}

50 women of reproductive age without severe generalsomatic and orthodontic pathologies have been examined. The subjects were assigned into groups according to their gynecological status: Group I (control) $(n=10)$ included women with the I and II degree of purity of the vagina; Group II $(n=10)$ included carriers of Gardnerella vaginalis without diagnosed bacterial vaginosis ; Group III-A $(n=15)$ included women with verified diagnosis of BV who received conventional treatment; Group III-B $(n=15)$ included women with $\mathrm{BV}$, who received treatment using our patented treatment regimen that takes into account the presence of specific BV-microflora found in the oral cavity in this group of subjects. The dental diagnosis was made on the basis of the conventional dental clinical, paraclinical, and X-ray examination suggested by N.F. Danilevsky (1994) [1]. Gynecologic diagnosis was made by an obstetrician-gynecologist using the Amsel's criteria. The results of the amino-test of the oral fluid were analyzed in the oral cavity [10]. Determination of the quantitative activity of alpha-amylase in saliva was carried out by the biochemical kinetic method [5]. Determination of the slgA concentration in mixed saliva was performed by the ELISA method [5]. In the mixed saliva, the presence of Gardnerella vaginalis and Atopobium vaginae in the oral cavity was determined by the polymerase chain reaction (PCR) method.

All subjects underwent professional oral hygiene and sanitation, closed curettage on indications. The subjects of the Group I and II received periodontal treatment according to conventional regimens, if necessary. Women of Group IIIA also received treatment according to conventional regimen: local treatment (oral rinses with "Stomatophyte" mouthwash after morning and evening hygienic procedures; applications with "Metrogyl-Denta" (for 7 days)); per os: 250 $\mathrm{mg}$ "Metronidazole" every 8 hours for 7 days, $50 \mathrm{mg}$ "Fluconazole" once daily (for 7 days), "Simbiter $\AA$ acidophilic concentrated" probiotic ( for 21 days).

The subjects of the Group III-B underwent treatment according to our patented regimen [11]. Local treatment included mouthwashes with "Stomatophyte" after morning and evening hygiene procedures (for 7 days), "Lizak" lozenges at a dosage of 1 lozenge every 6 hours for 5 days, gingival applications with "Metrogyl-Denta" twice a day. Upon completion treatment with "Stomatophyte", applications with "Simbiter® Omega" were prescribed in the silicone dentoalveolar baths overnight (for 21 days). The conventional treatment involved administration of $150 \mathrm{mg}$ Clindamycin every 6 hours (for 5 days), "Simbiter ${ }^{\circledR}$ acidophilic concentrated" probiotic (for 21 days), calcium-D3-Nicomed at a dosage of 1 tab. during evening meal (for 30 days). Treatment of subjects of the Group III was agreed with a gynecologist, taking into account the sensitivity of the BV etiological agents to antibiotic therapy. 
Local gynecological therapy involved "Fluomizin" vaginal suppositories every 24 hours (for 10 days), "Simbiter® gynecological" probiotic vaginally (for 21 days).

The findings were processed by the methods of variational statistics [4].

\section{Results and Discussion}

Dental clinical examination of the subjects of the Group I revealed clinically intact periodontium in $40 \%$ of women and chronic catarrhal gingivitis was diagnosed in $60 \%$. In Group II, only $30 \%$ of women had a clinically intact parodentium and chronic catarrhal gingivitis was registered in $70 \%$ of women. Chronic catarrhal gingivitis were diagnosed in $33.3 \%$ of the examined subjects of Group III-A; initial chronic generalized periodontitis in
$53.3 \%$; chronic generalized periodontitis of the first degree in $13.3 \%$. Chronic catarrhal gingivitis was found in $26.7 \%$ of subjects of Group III-B; initial chronic generalized periodontitis in $53.3 \%$ and chronic generalized periodontitis of the first degree in $20 \%$. The analysis of findings of the periodontal status has established that chronic inflammatory and inflammatory- dystrophic periodontal diseases were found in all subjects with BV, whereas no marked lesions of periodontal tissues were found in the group of women who are carriers of BV pathogens.

Findings of the study of individual factors of the local oral immunity, namely, alpha-amylase and sigA in mixed saliva are presented in Table 1.

Findings of the study of quantitative kinetic activity of alpha-amylase and slgA concentration in mixed saliva of examined women (M $\pm m$ )

\begin{tabular}{|l|c|c|c|c|}
\hline \multicolumn{1}{|c|}{ Indices } & $\mathrm{I}(10)$ & $\mathrm{II}(10)$ & $\mathrm{III}-\mathrm{A}(15)$ & $\mathrm{III}-\mathrm{B}(15)$ \\
\hline & & & $452.0 \pm 12.9^{*} \#$ & $443.63 \pm 10.91^{\star} \#$ \\
Alpha-amylase & \multirow{2}{*}{$230.81 \pm 17.42$} & $243.26 \pm 16.40$ & $\mathrm{p} 1<0.05$ & $\mathrm{p} 1<0.05$ \\
activity, units & & $\mathrm{p} 1>0.05$ & $\mathrm{p} 2<0.05$ & $\mathrm{p} 3>0.05$ \\
\hline & & & 97.05 \\
\hline & & $180.8 \pm 17.42$ & $\mathrm{p} 1<0.05$ & $93.53 \pm 4.35^{\star} \#$ \\
slgA content & $223.7 \pm 22.21$ & $\mathrm{p} 1>0.05$ & $\mathrm{p} 2<0.05$ & $\mathrm{p} 1<0.05$ \\
& & & $\mathrm{p} 2<0.05$ \\
\end{tabular}

Notes: in brackets - number of examined women,

* - significant difference $(p<0.05)$ in comparison with indices of Group I,

\#- significant difference $(p<0.05)$ in comparison with indices of Group II,

p1 - reliability of indices in comparison between Group I, II, III-A and III-B,

p2 - reliability of indices in comparison with Group II and III-A,

p3 - reliability of indices in comparison with Group III-A and III-B.

The rates of alpha-amylase activity in mixed saliva of ues and showed no significant difference between the groups. The results of examination of women with BV (Group III-A and III-B before treatment) showed no significant difference between the groups, but were much higher the physiological norm, which confirmed the presence of inflammatory process in the oral cavity. The content of slgA in the oral fluid in control and comparison groups varied within the reference values. The level of slgA in all examined subjects of Group III-A and III-B was reduced by $30-45 \%$, compared to a similar value in subjects without BV. The increase in kinetic activity of alphaamylase and decrease in slgA concentration in the saliva of subjects with BV confirms the presence of chronic inflammatory processes in the oral cavity of women with a specified gynecological disease. subjects of Group I and II were within the reference val-

Amino-test of the oral fluid in women of Group I and II showed negative result in all subjects. Positive values were registered in $86.6 \%$ and $93.3 \%$ of the subjects of Group III-A and III-B, respectively, before medical treatment. Amino-test of oral fluid promotes identification of BV-associated microflora in the oral cavity. Positive amino-test indicates the decline of individual resistance to BV etiological agents and the inability to inactivate their waste products, including volatile amine izonitryl, detected during the test.

Test on the presence of Gardnerella vaginalis and Atopobium vaginae in the oral cavity (namely, gingival sulcus or gingival, periodontal pockets) and vagina was made to objectify the correlations between vaginal dysbiosis and status of the oral biotope, as well as to confirm the results of the amino-test. The presence of microorganisms in both cavities was determined as a qualitative variable. The results are presented in Table 2 and 3.

Table 2

The results of the positive PCR on the presence of Gardnerella vaginalis in the oral and vaginal cavities of the examined women, \%

\begin{tabular}{|c|c|c|c|c|}
\hline Areas of diagnostics & $I(10)$ & II (10) & III-A (15) & III-B (15) \\
\hline Oral cavity & 0 & $\begin{array}{c}0 \\
\mathrm{p} 1>0.05\end{array}$ & $\begin{array}{c}84.6^{*} \# \\
\text { p1<0.05 } \\
\text { p2<0.05 }\end{array}$ & $\begin{array}{c}67.9^{*} \# \\
\text { p1<0.05 } \\
\text { p2<0.05 } \\
\text { p3 }>0.05\end{array}$ \\
\hline Vagina & 0 & $\begin{array}{c}100 \\
\mathrm{p} 1>0.05\end{array}$ & $\begin{array}{c}92.3^{*} \\
\text { p1<0.05 } \\
\text { p2<0.05 }\end{array}$ & $\begin{array}{c}96.4^{*} \# \\
\text { p1<0.05 } \\
\text { p2<0.05 } \\
\text { p3>0.05 }\end{array}$ \\
\hline
\end{tabular}

Notes: in brackets - number of examined women,

* - significant difference $(p<0.05)$ in comparison with indices of Group I,

\#- significant difference $(p<0.05)$ in comparison with indices of Group II,

p1 - reliability of indices in comparison between Group I, II and III,

p2 - reliability of indices in comparison with Group II and III,

$P P-\Pi$ - reliability of indices in comparison with the results of the oral cavity and vagina. 
Tom 23, N 3-4 2019 p.

Table 3

The results of PCR on the presence of Atopobium vaginae in the oral and virginal cavities of the examined women, \%

\begin{tabular}{|c|c|c|c|c|}
\hline Areas of diagnostics & $\mathrm{I}(10)$ & II (10) & III-A (15) & III-B (15) \\
\hline Oral cavity & 0 & $\begin{array}{c}0 \\
\mathrm{p} 1>0.05\end{array}$ & $\begin{array}{c}84.6^{\star} \# \\
\text { p1<0.05 } \\
\text { p2<0.05 }\end{array}$ & $\begin{array}{c}78.6^{*} \# \\
\text { p1<0.05 } \\
\text { p2<0.05 } \\
\text { p3 }>0.05\end{array}$ \\
\hline Vagina & 0 & $\begin{array}{c}0 \\
\mathrm{p} 1>0.05\end{array}$ & $\begin{array}{c}76.9^{*} \# \\
\text { p1<0.05 } \\
\text { p2<0.05 }\end{array}$ & $\begin{array}{c}78.6^{*} \# \\
\text { p1 }<0.05 \\
\text { p2 }<0.05 \\
\text { p3 }>0.05\end{array}$ \\
\hline
\end{tabular}

Notes: in brackets - number of examined women,

* - significant difference $(p<0.05)$ in comparison with indices of Group I,

\# - significant difference $(p<0.05)$ in comparison with indices of Group II,

p1 - reliability of indices in comparison between Group I, II and III,

p2 - reliability of indices in comparison with Group II and III,

$P P-\Pi$ - reliability of indices in comparison with the results of the oral cavity and vagina.

Gardnerella vaginalis was not found in any of the examined cavities of women with the I and II degree of purity of the vagina, which is normal for the microbial flora of both the vagina and the oral cavity.

The abovementioned microorganism has been found in all subjects who are carriers of Gardnerella vaginalis as commensal vaginal biotope, which is a logical result, since this group was formed on the basis of the presence of Gardnerella vaginalis, but without verified diagnosis of BV. In the oral cavity of women, Gardnerella vaginalis was not detected in any patient, which emphasizes the absence of the effect of this representative of vaginal microbiota on the state of periodontal tissues, if the vaginal normocenosis is not impaired.

In women with BV Gardnerella vaginalis was detected in the vaginal cavity by $18.5 \%$ more often, compared with the PCR results of the material from the oral cavity. Apparently, the high percentage of the prevalence of this etiological agent of BV in the oral cavity $(75.9 \%)$ gives evidence of cross-infection of the examined cavities.

The results of PCR for the presence of Atopobium vaginae confirmed the abovementioned results of Gardnerella vaginalis detection with regard to the influence of BV on the state of oral microbiota. In women of Group I and II no Atopobium vaginae was found both in the oral cavity and in the vagina. The percentage of the subjects

with confirmed presence of this microorganism in the oral cavity is by $3.7 \%$ higher the percentage found in vagina. The results of the examined cavities reach $80 \%$, which can be considered as a significant statistical confirmation of the correlation between the inflammatory and inflammatory-dystrophic periodontal tissues diseases and BV, as well as the impact on changes in local immunity. In addition, the comparison of the results of the PCRdiagnostics and the amino-test demonstrates the high diagnostic value of the latter.

After the course of treatment, a repeated clinical and laboratory examination of the women was performed. The comparison was made between groups of patients who were treated with different treatment regimens: conventional (III-A) and adapted to act against Gardnerella vaginalis and Atopobium vagina (III-B).

One of the criteria for efficacy of treatment is the period of elimination of the inflammatory process in periodontal tissues. Generally, the findings of the research have established the positive nature of changes in clinical indices of the state of oral cavity in all subjects in the dynamics of comprehensive treatment. On day 28 , the disappearance of clinical signs of gingival inflammation was diagnosed in $84.6 \%$ and $96.4 \%$ of the subjects of Group III-A and III-B, respectively. The results of the diagnostics of the state of local immunity are presented in Table 4. Table 4
with $B V$

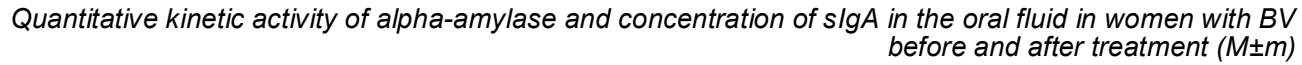

\begin{tabular}{|c|c|c|c|c|}
\hline \multirow{2}{*}{ Indices } & \multicolumn{2}{|c|}{ III-A (15) } & \multicolumn{2}{|c|}{ III-B (15) } \\
\hline & Before treatment & After treatment & Before treatment & After treatment \\
\hline $\begin{array}{l}\text { Alpha-amylase } \\
\text { activity, units }\end{array}$ & $452.0 \pm 12.9$ & $\begin{array}{c}325.30 \pm 15.17^{*} \\
\mathrm{p} 1<0.05\end{array}$ & $\begin{array}{c}443.63 \pm 10.91 \# \\
\text { p1 }>0.05 \\
\text { p2 }<0.05\end{array}$ & $\begin{array}{c}245.95 \pm 15.35^{\star} \#^{\circ} \\
\text { p1 }<0.05 \\
\text { p2 }<0.05 \\
\text { p3 }<0.05\end{array}$ \\
\hline slgA content & $97.47 \pm 4.43$ & $\begin{array}{c}145.87 \pm 13.12^{*} \\
\mathrm{p} 1<0.05\end{array}$ & $\begin{array}{c}93.53 \pm 4.35 \# \\
\text { p1 }>0.05 \\
\text { p2 }<0.05\end{array}$ & $\begin{array}{c}194.4 \pm 15.17^{*} \#^{\circ} \\
\text { p1 }<0.05 \\
\text { p2 }<0.05 \\
\text { p3 }<0.05\end{array}$ \\
\hline
\end{tabular}

Notes: in brackets - number of examined women,

* - significant difference $(p<0.05)$ in comparison with indices of Group III-A before treatment,

\#- significant difference $(p<0.05)$ in comparison with indices of Group III-A after treatment,

- significant difference $(p<0.05)$ in comparison with indices of Group III-B before treatment,

$p 1$ - reliability of indices in comparison between the results of Group III-A and III-B before and after treatment,

p2 - reliability of indices in comparison between the results of Group III-A after treatment and III-B before and after treatment,

p3 - reliability of indices in comparison of the results of Group III-B before and after treatment.

The analysis of the findings has shown no significant difference between the results of alpha-amylase activity and the content of slgA in the oral fluid in women of both groups before treatment, which confirms the similar con- ditions at the beginning of treatment. After treatment, in women of the Group III-A the kinetic activity of alphaamylase decreased by 126.7 units, but exceeded the reference values, which emphasizes the presence of in- 
flammatory process in the oral cavity. In subjects of Group III-B the same value decline by 197.68 units and was within the reference values, confirming the elimination of previously existing inflammation. Concentration of slgA in the oral fluid in both groups of women was restored after treatment, but the values of Group III-A and III-B significantly differed after treatment (the result of slgA in subjects of Group III-B was by 1.33 times higher than the value of Group III-A), indicating the higher efficacy of the proposed treatment regimen, which takes into account the presence of etiological agents of $\mathrm{BV}$ in the oral cavity.

To objectify the outcomes of treatment and the effect of the used drug regimens on Atopobium vaginae and Gardnerella vaginalis the amino-test of the oral fluid of women who underwent the prescribed therapy was made. In the subjects of Group III-A it was positive before treatment in $73.3 \%$; after treatment the rate was reduced to $53.3 \%$, whereas in the subjects of Group III-B the initial result was $80 \%$, and after treatment the decrease to $20 \%$ was recorded, indicating much more effective treatment proposed by us. A decrease in the percentage of positive amino-test indicates an increase in local resistance to etiological agents of bacterial vaginosis.

\section{Conclusions}

The study of individual factors of local oral immunity, such as alpha-amylase and slgA content in mixed saliva, in the dynamics of treatment of women with inflammatory and inflammatory-dystrophic periodontal diseases concomitant with bacterial vaginosis showed a significant deviation from the reference values of both indices, namely increase of kinetic activity of alpha-amylase and decrease in slgA concentration. After combined dental and gynecological treatment of patients the change in the studied indices showed more positive dynamics in women who were treated with the proposed treatment regimen, taking into account the presence of BV pathogens in the oral cavity. The analysis of the findings of the research with regard to the rates of local oral immunity and the results of the amino-test and PCR- diagnostics has concluded that the significant reduce in the presence of Gardnerella vaginalis and Atopobium vaginae in the oral cavity after treatment in women of Group III-B is in concordance with a significant improvement of the local immunity rates. The diagnostic value of the utilized labo- ratory methods of examination of women for their local resistance is sufficient for mass use as a control of the results of periodontal treatment of patients with inflammatory and inflammatory-dystrophic periodontal diseases concomitant with bacterial vaginosis.

\section{References}

1. Petrushanko T.O., Shulzhenko A.D., Krutikova E.I. Sostoyanie tkaney parodonta u zhenschin s bakterialnym vaginozom. Georg.Med.News 2014;12: 24-28.

2. Galich S.R. Bakterialnii vaginoz. Zdorov'e Ukrainy. 2012; 4(8):40-42.

3. Dyagterev E.N. Uroven' alfa-amilazy slyuny kak pokazatel' stressa u beremennyh. Region.anestez. i lechenie .ostroy boli. 2017;1(11):22-28.

4. Vyha G.V.,Serdyuk O.A., Vygodskaya T.V., Fursova A.V. Sekretorniy immunoglobulin A $\mathrm{V}$ kontrole adaptivnokompensatornyh reakcii organizma cheloveka. Med. Alfavit. Sovremen. Laboratoria. 2011;4:24-26.

5. Lapin A.A., Vyha G.V., Zelenkov V.N. Neinvazivniy metod opredeleniya antioksudantnogo statusa organizma. SPt. Netradic.prirod.resursy, tehnologii I produkti. 2011;19:920.

6. Sohov S.T., Aksamit L.A., Vyha G.V., Vorob'eva E.I., Tcvetkova A.A. Primenenie nesteroidnyh protivovospalitel'nyh sredstv dlya lecheniya stomatologicheskih zabolevaniy. Moskva. Medpress-inform. 2011. 82.

7. Kira E. F. Bakterialnii vaginoz. Moskva. MIA. 2012. 472

8. Kisina V.I., Zabirova K.I. Urogenital'nie infekcii u zhenschin: klinika, diagnostika, lechenie. Moskva. OOO «Medicinskoe informacionnoe agenstvo». 2005. 280.

9. Danilevskii N.F., Borisenko A.B. Zabolevaniya parodonta., Kiev.: Zdorov'ya. 2000. 464

10. Petrushanko T.O., Krutikova E.I., Shulzhenko A.D. Sposib likuvannya parodontytu u zhinok z bacterial'nym vaginozom.Patent Ukrainy na korysnu model № 120483, 10.11.2017. byul. № 23

11. Gerasimov A.N. Medicinskfya statistika. Uchebnoe posobie. Moskva. OOO «Medicinskoe informacionnoe agenstvo», 2007. 480.

12. Petrushanko T.O., Krutikova E.I., Shulzhenko A.D. Sposib ekspres-diagnostyky rotovoi ridyny na nayavnist' letyuchyh aminiv u zhinok $z$ bacterial'nym vaginozom.Patent Ukrainy na korysnu model № 99694, 25.06.2015. buyl. № 12.

13. Kaydashev I.P., Berkalo L.V., Bobovych O.V., Bobrova N.O. Metody klinichnih ta eksperemental'nyh doslidzhen'. Poltava. Polimed 2003. 320.

Матеріал надійшов до редакції 08.04.2019 p. 